\title{
Mild Forms of Alport Syndrome: Hereditary Nephropathy in the Absence of Extra-Renal Features
}

\author{
Han-Seung Yoon and Michael R. Eccles \\ Department of Pathology, Dunedin School of Medicine, University of Otago, Dunedin \\ New Zealand
}

\section{Introduction}

The type IV collagen nephropathies comprise a spectrum of abnormalities predominantly affecting the glomerular basement membrane (GBM) in the kidney, but also involving other organs such as the ear and eye. Type IV collagen nephropathies result from genetic mutations causing loss or deficiency of type IV collagen synthesis, and have been associated with Alport syndrome at one end of the spectrum, where individuals who are the most severely affected experience end-stage renal failure (ESRF) in their early teen-age years together with hearing loss and vision abnormalities. At the other end of the spectrum type IV collagen nephropathies are associated with mild defects, such as thin basement membrane nephropathy (TBMN) or benign familial hematuria where individuals may experience mild kidney abnormalities involving episodic hematuria but retain relatively normal renal function and show no extra-renal abnormalities. There are six different type IV collagen genes located on multiple chromosomes, and three of these genes (COL4A3, COL4A4, and COL4A5) are associated with X-linked, autosomal recessive or autosomal dominant inheritance patterns of Alport syndrome. In addition the type IV collagen genes are associated with the TBMN phenotype, involving heterozygous mutations of the COL4A3 and COL4A4 genes, with an autosomal dominant pattern of inheritance. The main focus of this chapter is the mild forms of Alport syndrome, and so in the following pages we review mild presentations of Alport syndrome, and illustrate this with a unique New Zealand family segregating mild X-linked Alport syndrome, some of whom display features of TBMN.

\section{Synthesis and distribution of type IV collagen}

The type IV collagen family is comprised of six homologous $\alpha$-chains designated $\alpha 1$ (IV)$\alpha 6$ (IV) encoded for by the COL4A1- 6 genes respectively, the corresponding genes of which are located pairwise on chromosomes 13q34, 2q36-37 and Xq22. Each $\alpha$-chain has three domains composed of a short 7S domain at the amino terminus, a long collagenous domain of approximately 1400 residues of Gly-Xaa-Yaa repeats and a noncollagenous (NC1) domain of about 230 residues at the carboxyl terminus (Figure 1). Three $\alpha$ chains assemble into triple-helical molecules called protomers that then assemble into supramolecular networks by the association of four protomers at the N-terminus, forming a $7 \mathrm{~S}$ tetramer, and the 
dimerization of two protomers at the C-terminus, forming an NC1 hexamer (Timpl et al., 1981). Interruptions in the Gly-Xaa-Yaa amino acid sequence at multiple sites along the collagenous domain give rise to flexibility, allowing for looping and supercoiling of protomers into networks (Hudson 2004, Miner 2003, Zhou \& Reeders 1996).

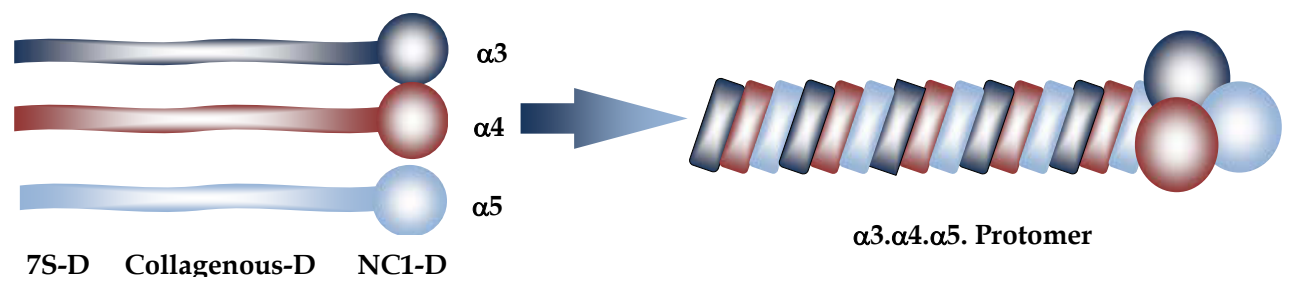

Fig. 1. A schematic drawing showing an example of $\alpha 3-, \alpha 4-$, and $\alpha 5$ (IV)-chains and $\alpha 3 . \alpha 4 . \alpha 5(\mathrm{IV})$ protomer formation. D: domain

To date, only three different types of collagen protomer have been identified; $\alpha 1 . \alpha 1 . \alpha 2(\mathrm{IV})$, $\alpha 3 . \alpha 4 . \alpha 5$ (IV) and $\alpha 5 . \alpha 5 . \alpha 6$ (IV) (Hudson 2004). The protomer $\alpha 1 . \alpha 1 . \alpha 2$ (IV) is ubiquitously present in most basement membranes (Hudson et al., 1993, Borza et al., 2001, Boutaud et al., 2000, Timpl et al., 1981). In contrast, $\alpha 3 . \alpha 4 . \alpha 5(\mathrm{IV})$ and $\alpha 5 . \alpha 5 . \alpha 6$ (IV) show restricted tissue distribution. In the kidney the $\alpha 1 . \alpha 1 . \alpha 2$ (IV)- $\alpha 1 . \alpha 1 . \alpha 2($ IV) network predominates during early nephrogenesis in the GBM, the Bowman's capsular basement membrane, and tubular basement membrane. As the kidney becomes mature during the $2^{\text {nd }}$ trimester of fetal development, the $\alpha 3 . \alpha 4 . \alpha 5$ (IV)- $\alpha 3 . \alpha 4 . \alpha 5$ (IV) network gradually becomes dominant and replaces the $\alpha 1 . \alpha 1 . \alpha 2$ (IV)- $\alpha 1 . \alpha 1 . \alpha 2$ (IV) network in the GBM and in tubular basement membranes while the $\alpha 1 . \alpha 1 . \alpha 2(\mathrm{IV})-\alpha 5 . \alpha 5 . \alpha 6(\mathrm{IV})$ and the $\alpha 1 . \alpha 1 . \alpha 2(\mathrm{IV})-\alpha 1 . \alpha 1 . \alpha 2(\mathrm{IV})$ networks are distributed in the Bowman's capsular basement membrane and in tubular basement membranes (Harvey et al., 1998, Milner 2003). The protomer $\alpha 3 . \alpha 4 . \alpha 5$ (IV) is also expressed in the lung, testis, cochlea and eye while the $\alpha 5 . \alpha 5 . \alpha 6$ (IV) network is present in skin, smooth muscle and esophagus (Cosgrove et al., 1998, Hudson et al., 2003, Kalluri et al., 1997). Alterations in any of the COL4A3, COL4A4 and COL4A5 genes may cause Alport syndrome.

\section{Alport syndrome}

Alport syndrome is a hereditary disorder with considerable genetic and clinical heterogeneity characterized by hematuria, proteinuria (1-2 gm of protein per day) and progressive renal failure and is frequently associated with diagnostic ocular abnormalities and high tone sensorineural deafness. Ocular abnormalities include lenticonus of the anterior lens capsule, retinopathy and cataracts. Other extra-renal manifestations include mental retardation or leiomyomatosis in rare cases (Alport 1927, Flinter et al., 1988, Hudson et al., 2003).

\subsection{Genetics}

In approximately $85 \%$ of patients with Alport syndrome there is X-linked inheritance of mutations in the COL4A5 gene encoding the $\alpha 5(\mathrm{IV})$ collagen chain on chromosome Xq22. COL4A5 is a large gene comprising 51 exons. As many as 588 mutations have been described to date and are spread throughout the gene without any identified mutational hot spots. The types of mutations that involve COL4A5 consist of missense, deletion, splice site, nonsense, insertion and duplication mutations (Hou et al., 2007, Mochizuki et al., 1994). 
The remaining $15 \%$ of Alport syndrome patients show autosomal inheritance; of these $14 \%$ are recessive and $1 \%$ are dominant, which are caused by mutations either in the COL4A3 or COL4A4 genes on chromosome 2 q36-37 encoding the $\alpha 3(\mathrm{IV})$ or $\alpha 4(\mathrm{IV})$ proteins. Heterozygous mutations of COL4A3 or COL4A4 could result in a less severe phenotype than that of homozygous or compound mutations in these genes (Jefferson et al., 1997). The authors also noted that heterogygous mutations of these genes could result in thin basement membrane nephropathy (TBMN) which typically does not result in renal failure. The authors postulated that mutations in the COL4A3 or COL4A4 gene can cause a spectrum of disease, ranging from TBMN/benign familial hematuria to autosomal dominant and recessive forms of Alport syndrome.

\subsection{Pathogenesis}

Ultrafiltration of plasma in the renal glomeruli is the major function of the kidney (Voskarides et al., 2008). The primary filtration barrier of the glomerular capillary consists of three layers: the fenestrated endothelial cells, the intervening GBM, and the epithelial podocyte foot processes. The foot processes are connected to each other by the slit diaphragm, and together these constitute an important component of the filtration barrier; the loss of podocyte foot processes results in massive proteinuria. The GBM is a special kind of acellular extracellular matrix, having properties of a viscous gel. The filtration barrier behaves as a selective sieve restricting the passage of macromolecules on the basis of their size, shape, and charge. Deterioration of the integrity of the GBM results in mild proteinuria. The major constituent of GBM is type IV collagen, which together with laminin, nidogen, and sulfated proteoglycans maintains the filtration barrier and provides the substrata and signals necessary for proper renal cell function (Hudson \& Tryggvason 2003).

Mutations present in Alport syndrome that produce post-translational defects in $\alpha 3(\mathrm{IV})$, $\alpha 4(\mathrm{IV})$, or $\alpha 5(\mathrm{IV})$ chains may result in incorrect folding or assembly of monomers. Such defective monomers are rapidly degraded. The mutations, therefore, arrest the normal developmental maturation during the fetal $2^{\text {nd }}$ trimester period when the $\alpha 1 . \alpha 1 . \alpha 2(\mathrm{IV})$ network is largely replaced by the $\alpha 3 . \alpha 4 . \alpha 5$ (IV) network in the GBM. This maturation may be related to oxidative and physical stress in GBM (Kalluri et al., 2000) and perhaps also in the cochlea (Huang et al., 2000) and the lens capsule (Reddan et al., 1996). In the kidney, as plasma traverses glomerular capillaries, the protein content, including the levels of serum proteases, increases. The embryonic $\alpha 1 . \alpha 1 . \alpha 2$ (IV) network is more susceptible to endoproteolysis than the more heavily cross-linked $\alpha 3 . \alpha 4 . \alpha 5$ (IV) network (Kalluri et al 1997). It seems, then, that GBM that is more exposed to proteases or oxidants needs the protection of a resistant collagen IV network. Over time, patients with Alport syndrome probably become more sensitive to proteolysis, which may explain why their glomerular membranes thicken unevenly, split, and ultimately deteriorate (Kalluri et al., 1997, Kalluri et al., 2000). Immunohistochemical studies show that mutations in the COL4A5 gene, which cause the X-linked form of Alport syndrome, frequently result in the loss of all three of the $\alpha 3($ IV), $\alpha 4(\mathrm{IV})$ and $\alpha 5$ (IV) chains in the GBM (Naito et al., 1996, Naito et al., 2003, Yoshioka et al., 1994). Thus, the absence of a functionally normal $\alpha 5$ (IV) chain can disrupt assembly of the triple-helical protomer, and frequently leads to loss of the entire $\alpha 3 . \alpha 4 . \alpha 5(\mathrm{IV})$ network in the GBM.

Mutations involving the NC1 domain of COL4A5 result in no or severely reduced

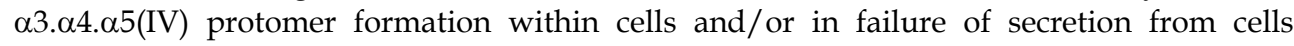


(Kobayashi T et al., 2008, Kobayashi \& Uchiyama 2010). In the normal process of formation of the type IV collagen network, the NC1 domain plays an important role in forming protomers as three $\alpha$ chains specifically interact with each other. Additionally, in forming NC1 hexamers, two protomers dimerize at the C-terminus. Defective monomers or protomers of type IV collagen networks may be degraded rapidly.

\section{Genotype-phenotype correlation in X-linked Alport syndrome}

Approximately six hundred mutations in COL4A5 have been reported, 588 of which are causally linked with X-linked Alport syndrome (Arup Laboratories 2011). Considerable allelic heterogeneity is observed by the high number of mutations and the associated phenotypic variability. Clinically the natural history of the nephropathy and other extrarenal lesions are quite variable. A number of researchers have attempted to link genotypes in Alport syndrome to phenotypes (Bekheirnia et al., 2010, Gross et al., 2002, Jais et al., 2000). Gross and colleagues have proposed a classification linking phenotype and genotype into three categories (Gross et al., 2002).

- Type S (severe); genotypic alterations in COL4A5 include major gene rearrangements, premature stop codons, frameshift mutations, and donor splice site alterations. Also includes mutations involving the NC1 domain. The phenotype is characterised by early onset of ESRF at about 20 years of age and significant extra-renal manifestations including $80 \%$ with sensorineural deafness and $40 \%$ with ocular lesions.

- Type MS (moderately severe). The genotype in this group is characterised by nonglycine-XY missense alterations, in-frame deletions/insertions, acceptor splice site changes and glycine- $X Y$ substitutions involving exons 21-47. This type is associated with ESRF appearing in the mid-twenties with about $65 \%$ of individuals having hearing loss and $30 \%$ ocular defects.

- $\quad$ Type M (moderate). The genotype is glycine-XY substitutions involving exons 1-20. The phenotype appears to be milder with a later onset of ESRF at about 30 years of age, including a significant number of individuals with sensorineural deafness (70\%) and ocular lesions (30\%).

Bekheirnia and colleagues have confirmed previous reports (Gross et al., 2002, Jais et al., 2000) in that there is a strong genotype-phenotype correlation in X-linked Alport syndrome (Bekheirnia et al., 2010). The authors conclude that missense mutations are associated with the best prognosis with an average age at onset of ESRF of $37 \mathrm{yr}$, followed by splice site mutations at $28 \mathrm{yr}$, truncating mutations at $25 \mathrm{yr}$ and small deletions at 22 yr. The authors also point out a strong relationship between mutation position and age onset of ESRF, with younger ages at onset of ESRF associated with the 5' end of the gene. Affected males with splice mutations or truncating mutations showed two-fold greater odds of developing eye problems and hearing loss than those with missense mutations. Mutations associated with hearing loss and ocular changes are located closer to the $5^{\prime}$ end of the gene.

\section{Mild forms of Alport syndrome}

While many affected males of X-linked Alport syndrome show moderate to severe forms of nephropathy and extra-renal abnormalities between the second and third decades, it is also well known that there are occasional milder cases where ESRF may be delayed until 
the fifth or sixth decade along with variable age occurrence of deafness (Bekheirnia et al., 2010, Kobayashi et al., 2008, Smeets et al., 1992). Of the six hundred or so COL4A5 mutations that have been reported to date (Arup Laboratories 2011), 588 mutations were pathogenic for X-linked Alport syndrome, whereas 12/600 mutations were benign (silent). A total of $81 / 588$ mutations $(13.8 \%)$ were associated with a mild form of Alport syndrome where the age of onset of ESRF was over $30 \mathrm{yr}$ old. These 81 mutations of a mild form are shown in Figure 2 and consist of 66 mutations within exons (red column) and 15 mutations within introns (blue column), widely distributed over the COL4A5 gene. It appears that mutations involved in a mild form of Alport syndrome are widely distributed within 51 exons of the COL4A5 gene with a tendency for more mutations between Exon 25 to 51.

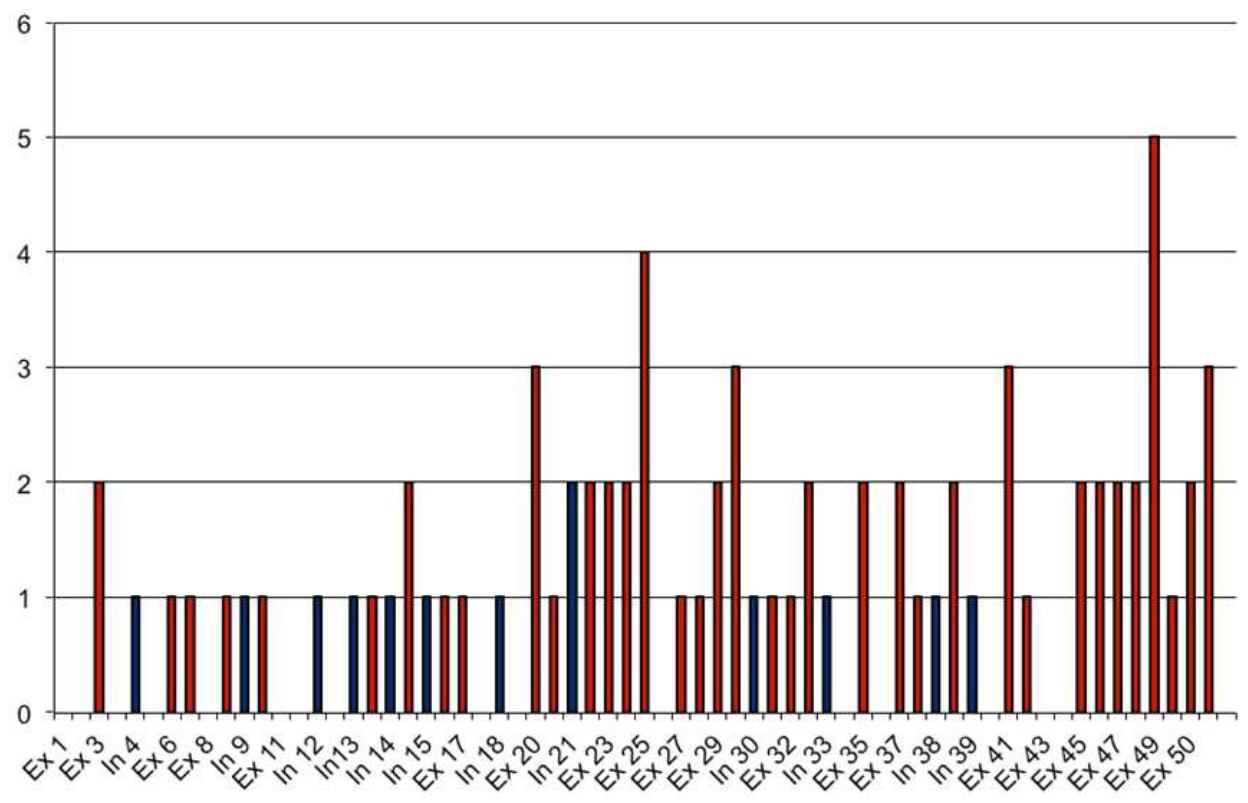

Fig. 2. Distribution and frequency of mutations in exons (red column) and introns (blue column) within the COL4A5 gene causally relating to X-linked Alport syndrome (Arup Laboratories 2011).

\section{A unique mild form of Alport syndrome in New Zealand families}

We previously described a novel Cys1638Tyr alteration in the NC1 domain of COL4A5 identified in a large New Zealand family (Fig 3) with a hereditary nephropathy (Wilson et al., 2007). This family was identified when two sisters (IV26 and IV28) presented to the clinic to be considered as potential live kidney donors for their sons (V29 and V35, respectively) who had ESRF (see Tables 1 and 2). Both women were found to have significant proteinuria and hypertension and so it was decided to carry out renal biopsies. Following the results of the biopsies each family member was then evaluated for the presence of renal disease as indicated in Table 1, and only three male members of the extensive pedigree were found to 
exhibit ESRF. Extra-renal manifestations such as sensorineural deafness or ocular changes were not observed in any family member. Further renal biopsies were carried out on additional family members, so that renal biopsies now totalled eight members of the family. The biopsies from a 39 year-old male with proteinuria of $1.1 \mathrm{~g} / 24 \mathrm{~h}$ and normal auditory and eye examination (V42) showed mild increase of mesangial matrix and mild periglomerular Bowman capsular fibrosis (Fig 4A). There were occasional areas showing focal interstitial accumulation of foam cells (Fig 4B), interstitial fibrosis (Fig 4C) and thick-wall hyalinized vessels surrounded by scattered aggregates of lymphocytes (Fig 4D).

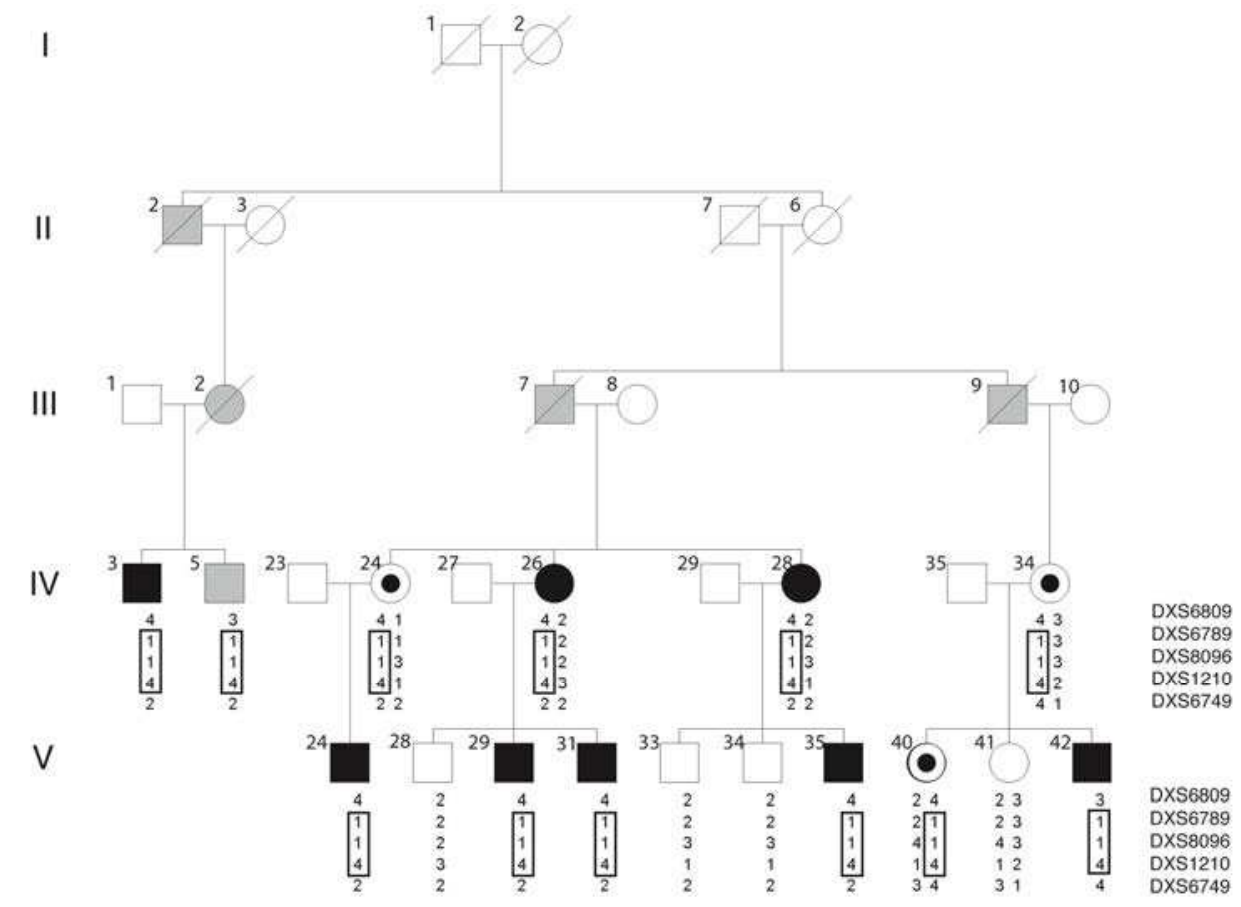

Fig. 3. Family pedigree. A simplified pedigree of the family showing males (squares) and females (circles) depicted by generation (I-V) is shown. While the disease appears severe in this pedigree, the extended pedigree was published previously (Wilson et al., 2007), and only $32 / 155$ members of the extended pedigree are shown in this diagram. Some of the individuals indicated in Tables 1 and 2 are represented in this pedigree and are identified in each case by their corresponding number. Black symbols indicate individuals with biopsy-confirmed GN. Black dots inside the symbols indicate obligate carriers. Grey symbols indicate individuals who were not biopsied, with clinical manifestations of renal disease and therefore presumed GN. Open symbols indicate individuals without clinical signs of renal disease. $\mathrm{X}$ chromosome region markers (Xq21.33-Xq23) informative for linkage analysis are indicated on the right, and shown below the symbols are the genotypes for each individual that are associated with the relevant marker. The boxed region indicates a common haplotype inherited from the father or the mother, corresponding to genotypes of the 3 markers that segregate with the disease. The genomic region of chromosome $\mathrm{X}$ corresponding to this haplotype contained the COL4A5 gene locus. 


\begin{tabular}{|c|c|c|c|c|c|}
\hline $\begin{array}{l}\text { Identification } \\
\text { number }\end{array}$ & $\begin{array}{l}\text { Age } \\
\text { Gender }\end{array}$ & Presentation & $\begin{array}{l}\text { Renal Function and } \\
\text { Blood Pressure }\end{array}$ & Biopsy * & Inheritance \\
\hline III2 & Female & & Died on dialysis & Not done & $\begin{array}{l}\text { Affected/ } \\
\text { Carrier }\end{array}$ \\
\hline IV3 & $\begin{array}{l}57 \text { yrs old } \\
\text { male }\end{array}$ & & $\begin{array}{l}\text { ESRF at } 40 \text { yrs old. } \\
\text { Dialysis. Renal } \\
\text { transplant. }\end{array}$ & Not done. & Affected \\
\hline IV5 & $\begin{array}{l}46 \text { yrs old } \\
\text { male }\end{array}$ & $\begin{array}{l}\text { Proteinuria } \\
4.7 \mathrm{~g} / 24 \mathrm{~h} \\
\text { Hypertension }\end{array}$ & $\begin{array}{l}\text { Chronic kidney } \\
\text { disease BP 200/120 }\end{array}$ & Not done & Affected \\
\hline V24 & $\begin{array}{l}39 \text { yrs old } \\
\text { male }\end{array}$ & $\begin{array}{l}\text { Proteinuria. } \\
\text { Hematuria }\end{array}$ & BP 148/90 & $\begin{array}{l}\text { Mild } \\
\text { mesangial } \\
\text { matrix } \\
\text { expansion }\end{array}$ & Affected \\
\hline V29 & $\begin{array}{l}41 \text { yrs old } \\
\text { male }\end{array}$ & $\begin{array}{l}\text { Acute nephritic } \\
\text { syndrome. } \\
\text { Hypertension } \\
\end{array}$ & $\begin{array}{l}\text { ESRF at } 28 \text { yrs old. } \\
\text { Dialysis. } 2^{\text {nd }} \text { renal } \\
\text { transplant }\end{array}$ & $\begin{array}{l}\text { Chronic } \\
\text { glomerulo- } \\
\text { nephritis } \\
\end{array}$ & Affected \\
\hline V31 & $\begin{array}{l}36 \text { yrs old } \\
\text { male }\end{array}$ & $\begin{array}{l}\text { Proteinuria. } \\
\text { Hypertension }\end{array}$ & $\begin{array}{l}\text { Chronic kidney } \\
\text { disease } \\
\text { BP 136/86 }\end{array}$ & $\begin{array}{l}\text { Mesangial } \\
\text { cell } \\
\text { proliferation. }\end{array}$ & Affected \\
\hline V35 & $\begin{array}{l}32 \text { yrs old } \\
\text { male }\end{array}$ & $\begin{array}{l}\text { Proteinuria. } \\
\text { Hematuria }\end{array}$ & $\begin{array}{l}\text { Chronic kidney } \\
\text { disease. Progressed } \\
\text { to ESRF, at } 26 \text { yrs } \\
\text { old and renal } \\
\text { transplant }\end{array}$ & $\begin{array}{l}\text { Chronic } \\
\text { glomerulo- } \\
\text { nephritis }\end{array}$ & Affected \\
\hline $\mathrm{V} 42$ & $\begin{array}{l}39 \text { yrs old } \\
\text { male }\end{array}$ & $\begin{array}{l}\text { Proteinuria } \\
1.1 \mathrm{~g} / 24 \mathrm{hr}\end{array}$ & BP 126/80 & $\begin{array}{l}\text { Mesangial } \\
\text { cell } \\
\text { proliferation. }\end{array}$ & Affected \\
\hline
\end{tabular}

* Ig immunofluorescence negative

Table 1. Renal disease identified prior to mutation screening in the New Zealand family

Electron microscopy of a renal biopsy from (V42), of which histology is shown in Fig 4, demonstrated a classical basket weave pattern or splitting of the basement membrane characteristic of Alport syndrome (Fig 5A and 5B). However, a diagnosis of Alport syndrome was not necessarily an obvious diagnosis in this family, since the disease in all three males was relatively mild and there was a lack of extra-renal manifestations in any of the family members, raising some doubts as to whether this was Alport syndrome prior to carrying out genetic analysis.

To determine the genetic cause of the disease in this family, genomic DNA was isolated from whole blood of each of the family members, and used in linkage analysis with genetic markers spanning chromosome $X$ carried out as described in Wilson et al (2007). Strong evidence for linkage to markers DXS6789, DXS8096, DXS1210, adjacent to the COL4A5 (and COL4A6) genes located on chromosome $X$ was obtained, indicating that this corresponded to a collagen nephropathy in the family, and that it was most likely due to a mutation in COL4A5. 


\begin{tabular}{|c|c|c|c|c|c|}
\hline $\begin{array}{l}\text { Identification } \\
\text { number }\end{array}$ & $\begin{array}{l}\text { Age } \\
\text { Gender }\end{array}$ & Presentation & $\begin{array}{l}\text { Renal Function and } \\
\text { Blood Pressure }\end{array}$ & Biopsy * & Inheritance \\
\hline IV24 & $\begin{array}{l}69 \text { yrs old } \\
\text { female }\end{array}$ & $\begin{array}{l}\text { Trace } \\
\text { microscopic } \\
\text { hematuria }\end{array}$ & $\begin{array}{l}\text { Normal renal } \\
\text { function. } \\
\text { BP 168/86 }\end{array}$ & Not done & Carrier \\
\hline IV26 & $\begin{array}{l}64 \text { yrs old } \\
\text { female }\end{array}$ & $\begin{array}{l}\text { Proteinuria } \\
1.8 \mathrm{~g} / 24 \mathrm{hr} \\
\text { Hypertension. }\end{array}$ & $\begin{array}{l}\text { Normal renal } \\
\text { function } \\
\text { BP 152/76 }\end{array}$ & $\begin{array}{l}\text { Mesangial cell } \\
\text { proliferation. } \\
\text { Hypertensive } \\
\text { arteriosclerosis }\end{array}$ & $\begin{array}{l}\text { Affected/ } \\
\text { Carrier }\end{array}$ \\
\hline IV28 & $\begin{array}{l}60 \text { yrs old } \\
\text { female }\end{array}$ & $\begin{array}{l}\text { Proteinuria } \\
1.4 \mathrm{~g} / 24 \mathrm{hr} \\
\text { Hypertension }\end{array}$ & BP 160/98 & $\begin{array}{l}\text { Mesangial cell } \\
\text { proliferation. } \\
\text { Hypertensive } \\
\text { arteriosclerosis }\end{array}$ & $\begin{array}{l}\text { Affected/ } \\
\text { Carrier }\end{array}$ \\
\hline IV31 & $\begin{array}{l}69 \text { yrs old } \\
\text { female }\end{array}$ & $\begin{array}{l}\text { Hypertension } \\
\text { Negative urine }\end{array}$ & $\begin{array}{l}\text { Normal renal } \\
\text { function }\end{array}$ & Not done & Carrier \\
\hline IV34 & $\begin{array}{l}65 \text { yrs old } \\
\text { female }\end{array}$ & $\begin{array}{l}\text { Hypertension } \\
\text { Negative urine }\end{array}$ & $\begin{array}{l}\text { Normal renal } \\
\text { function }\end{array}$ & Not done & Carrier \\
\hline IV36 & $\begin{array}{l}61 \text { yrs old } \\
\text { female }\end{array}$ & $\begin{array}{l}\text { Microscopic } \\
\text { hematuria }\end{array}$ & $\begin{array}{l}\text { Normal renal } \\
\text { function }\end{array}$ & Not done & Carrier \\
\hline IV39 & $\begin{array}{l}72 \text { yrs old } \\
\text { male }\end{array}$ & $\begin{array}{l}\text { Proteinuria } \\
1.6 \mathrm{~g} / 24 \mathrm{hr} \\
\text { No hematuria } \\
\text { Hypertension }\end{array}$ & $\begin{array}{l}\text { Mild chronic kidney } \\
\text { disease } \\
\text { BP 144/76 }\end{array}$ & Not done & Affected \\
\hline IV47 & $\begin{array}{l}54 \text { yrs old } \\
\text { female }\end{array}$ & $\begin{array}{l}\text { Hematuria } \\
\text { Hypertension }\end{array}$ & $\begin{array}{l}\text { Normal renal } \\
\text { function } \\
\text { BP 148/70 }\end{array}$ & Not done & Carrier \\
\hline V44 & $\begin{array}{l}36 \text { yrs old } \\
\text { female }\end{array}$ & $\begin{array}{l}\text { Intermittent } \\
\text { microscopic } \\
\text { hematuria }\end{array}$ & $\begin{array}{l}\text { Normal renal } \\
\text { function } \\
\text { BP 120/76 }\end{array}$ & Not done & Carrier \\
\hline V49 & $\begin{array}{l}43 \text { yrs old } \\
\text { female }\end{array}$ & Negative urine & $\begin{array}{l}\text { Normal renal } \\
\text { function } \\
\text { BP } 120 / 70\end{array}$ & Not done & Carrier \\
\hline V37 & $\begin{array}{l}39 \text { yrs old } \\
\text { female }\end{array}$ & Negative urine & $\begin{array}{l}\text { Normal renal } \\
\text { function }\end{array}$ & Not done & Carrier \\
\hline V40 & $\begin{array}{l}42 \text { yrs old } \\
\text { female }\end{array}$ & Hematuria & $\begin{array}{l}\text { Normal renal } \\
\text { function. } \\
\text { BP 118/70. }\end{array}$ & \begin{tabular}{|l} 
Mild \\
mesangial cell \\
proliferation \\
\end{tabular} & Carrier \\
\hline
\end{tabular}

* Ig immunofluorescence negative

Table 2. Renal disease or carrier status identified after mutation screening in the NZ family 

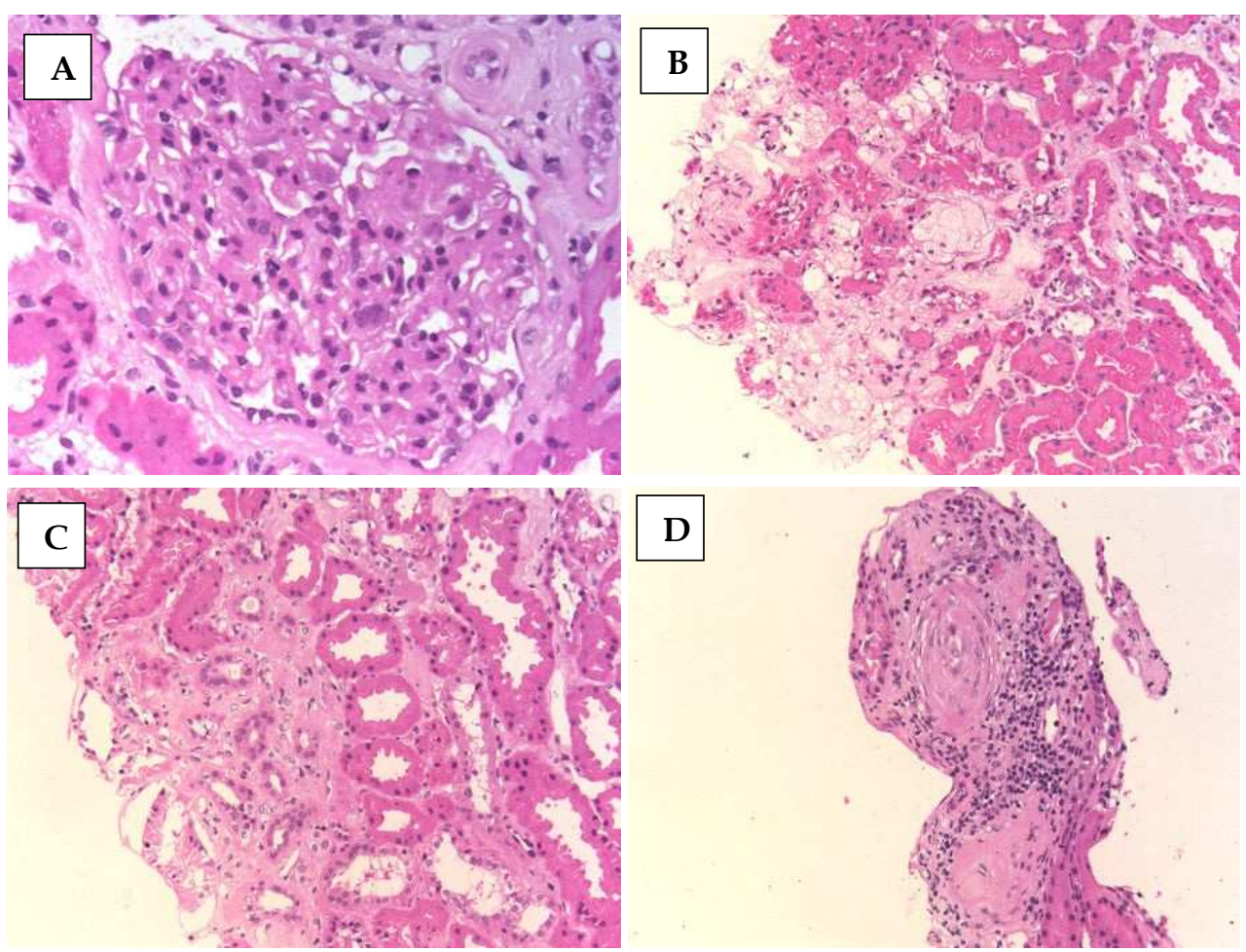

Fig. 4. Histological findings of the kidney of a patient, $39 \mathrm{yr}$ old male with hematuria, proteinuria $1.1 \mathrm{~g} / 24 \mathrm{~h}$ and normal auditory and eye examination. (A) Glomerulus from kidney biopsy of this patient showing mild periglomerular fibrosis and mild mesangial matrix increase. Tubular atrophy is seen at the right upper corner. (B) Focal accumulations of foam cells in the interstitium. (C) Multiple focal areas of interstitial fibrosis associated with atrophic tubules. (D) Sclerosed vessels surrounded by lymphocytes.

Eventually the mutation, comprising a c.4913G>A nucleotide substitution in exon 50 of COL4A5, was identified by PCR amplification and sequenced following analysis using a series of primer pairs corresponding to each of the 51 exons making up the COL4A5 transcript (Genbank accession number NM_000495) as well as the entire promoter region between COL4A5 and COL4A6. Therefore, this analysis conclusively showed that the disease in this family was a mild form of Alport syndrome.

Since it is known that most cases of Alport syndrome result in loss of the synthesis or secretion of the collagen protein and/or protomer, which can be detected by the absence of the collagen staining by immunohistochemistry, in order to further understand whether the pathogenesis of this disease in the New Zealand family was due to the loss of synthesis of COL4A5, immunohistochemical studies of the $\alpha 1$ to $\alpha 5$ type IV collagens in kidney biopsies from affected and carrier individuals were carried out. This analysis showed that in affected men (V31, V35 and V42) and carriers (IV26 and IV28) the GBMs were positive for $\alpha 1$ to $\alpha 5$ type IV collagens, as exemplified in Fig $6(\alpha 3, \alpha 4$ and $\alpha 5)$. These findings were considerably different from the previous reports of Alport syndrome, where the X-linked form of Alport 
syndrome was generally found to result in the loss of all three of the $\alpha 3(\mathrm{IV}), \alpha 4(\mathrm{IV})$ and $\alpha 5(\mathrm{IV})$ chains in the GBM.
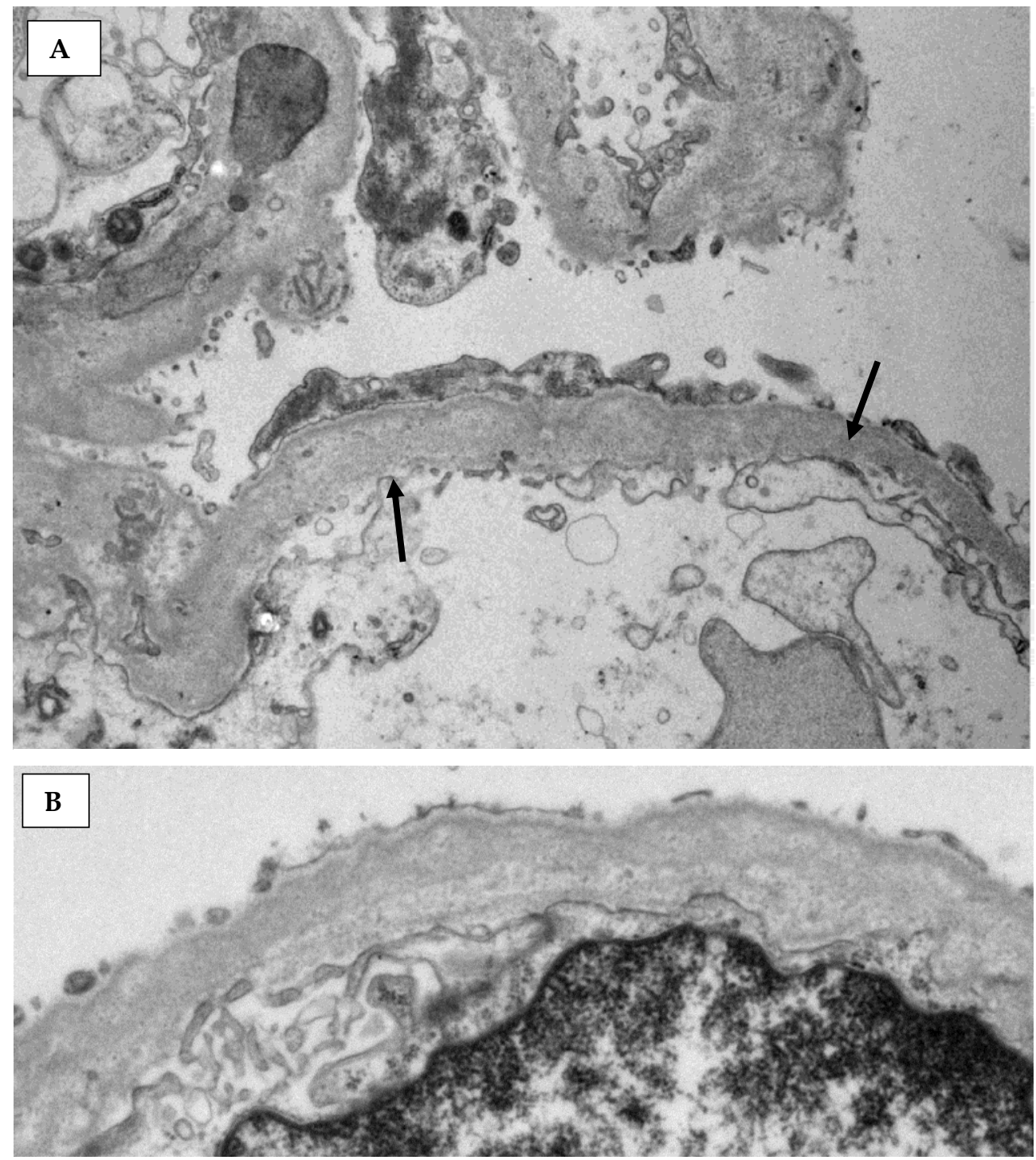

Fig. 5. Electron microscopy of glomerular basement membranes of the same patient (V42) of Figure 4. (A) Characteristic splitting or basket weave appearance of GBM (arrows) and abnormal podocyte foot processes. (original magnification x9,700). (B) Higher magnification of a basket weave appearance. (original magnification $\times 13,500$ ). Note, the ultra-structural changes in the glomerular basement membrane of patients with Alport syndrome were variably associated with areas of thick and thin basement membrane, and/or presence of a basket-weave pattern. 

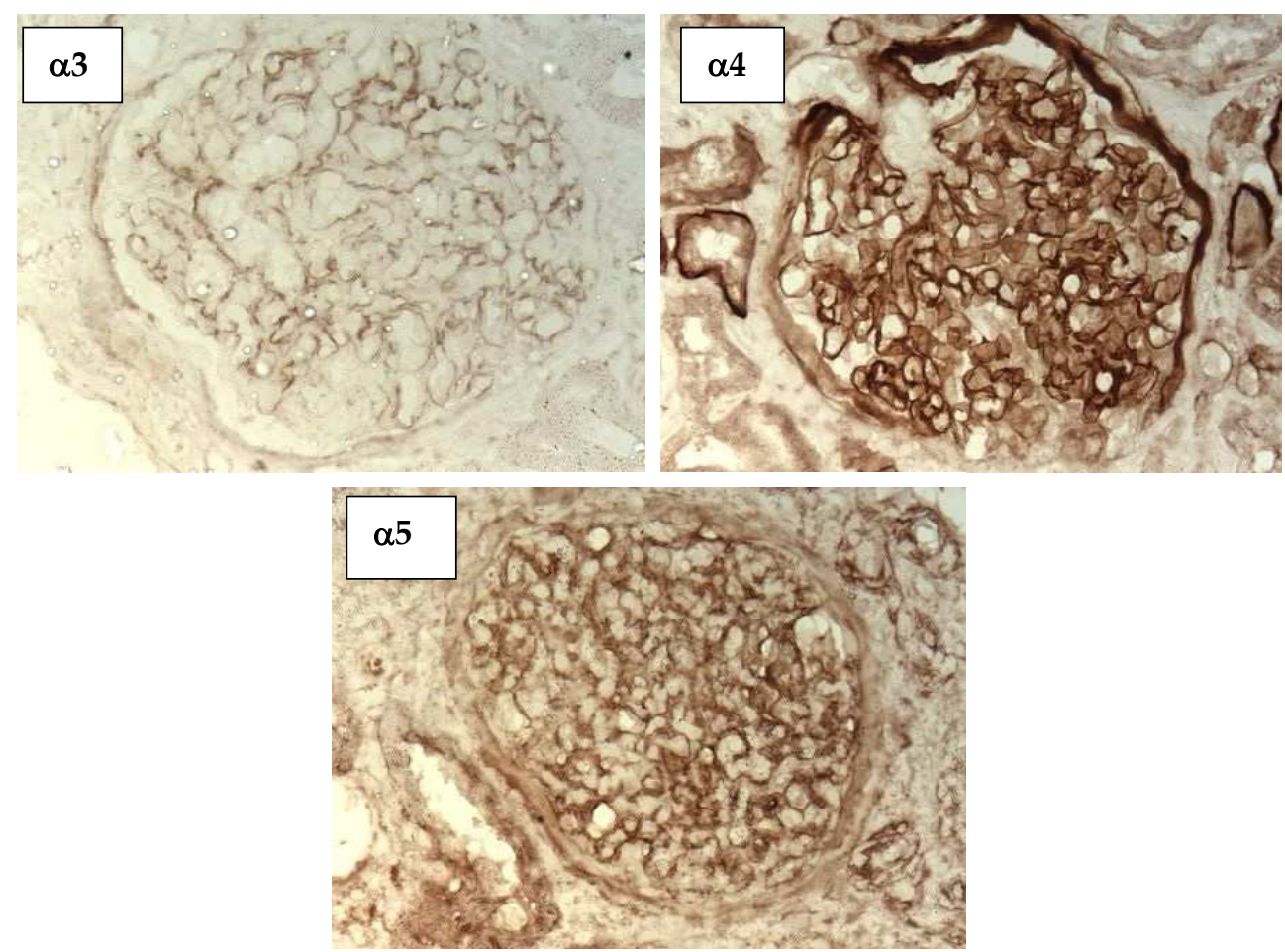

Fig. 6. Immunohistochemistry using monoclonal antibodies against $\alpha \mathrm{IV}$ collagen in a kidney biopsy shows $\alpha 3, \alpha 4$ and $\alpha 5$ positivity in the GBM.

Unlike most other reports of Alport syndrome, and inconsistent with the disease severity and multi-organ involvement that is generally associated with NC1 mutations, the major manifestation of the renal abnormality in the New Zealand family was proteinuria, which occurred in six of the nine male members who carried the COL4A5 mutation. Only three of the nine males in the family who inherited the mutation presented with glomerulonephritis and ESRF.

The NC1 domain plays an important role in the selection of $\alpha$ chains for assembly into heterotrimers. In general, substitution and missense mutations in the NC1 domain, as in other regions of COL4A5, lead to hematuria, proteinuria, ESRF and sensorineural hearing loss with an overwhelming predominance in males (Barker et al., 1996, Barker et al., 1997, Gross et al., 2002, Hertz et al., 2001, Inoue et al., 1999, Knebelmann et al., 1996, Nakanishi et al., 1994, Netzer et al., 1996, Zhou et al., 1991). A previous study classified X-linked Alport syndrome patients caused by mutations involving the NC1 domain into Type S (severe) phenotype (Gross et al., 2002). Mutations involving other cysteine residues in the NC1 domain have also been reported and include C1486S (Zhou et al., 1991), C1567R (Knebelmann et al., 1996) and C1586R (Hertz et al., 2001) and others (see Figure 7).

Using the proposed classification suggested by Gross and colleagues, the New Zealand family would be placed in 'type $S$ ' on the basis of the mutant genotype involving the NC1 domain. However, none of the family members had a phenotype as severe as reported previously in association with NC1 domain mutations. In all cases the presentation of renal 
disease in the affected male members of the New Zealand family was relatively late. The lack of extra-renal manifestations in the males is also contrary to previous reports correlating NC1 mutations with 'type S' Alport syndrome.

Therefore, while NC1 domain mutations in COL4A5 are thought to be associated with severe forms of Alport syndrome, the pattern of disease in this family was comparatively mild, and only $27 \%$ of the affected or presumed obligate mutant males in the family developed end-stage renal disease. Indeed, considerable variability and phenotypic heterogeneity in the extent of renal disease was observed in the affected males and carrier females. For example, one family member, a 72 year-old male (IV39) shown in Table 2, was later found to carry the sequence alteration, and was initially apparently phenotypically unaffected, but then further investigation revealed proteinuria $(1.6 \mathrm{~g} / 24 \mathrm{~h})$ and hypertension. This man was not biopsied. Furthermore, the presentation of ESRF in one female carrier in this study (III2) leads to the conclusion that female carriers were also affected. Skewed inactivation of the $X$ chromosome could account for this, although other genetic or environmental factors, such as hypertension, could also be contributing factors to the variability in disease progression. This amount of phenotypic variation between males and females is unusual in Alport syndrome, and even more unusual is the fact that none of the family members exhibited the full spectrum of renal, auditory and ocular abnormalities typifying Alport syndrome. The inheritance pattern was clearly consistent with an X-linked dominant mode, albeit with reduced penetrance, as the linkage analysis, together with the scan of the entire COL4A5 gene for the mutation, clearly identified that the NC1 domain mutation identified in COL4A5 was the causative mutation in this family.

The Cys1638Tyr alteration in the New Zealand family is predicted to affect the 10th conserved cysteine residue among 12 cysteine residues in the NC1 domain, thus disrupting the disulfide bond linking the C-terminal $\beta 3^{\prime}-\beta 4^{\prime}$ hairpin (Fig 7). In the kidney GBM the $\beta 3^{\prime}$ to $\beta 4^{\prime}$ disulfide-bridge could be involved in inter-molecular rather than intra-molecular interactions. For example, inter-protomer disulfide cross-links, or interactions with other molecules, such as integrins could involve formation of disulfide linkages to the cysteine residues at positions $66,72,177$ or 183 in the $N$-terminal or C-terminal $\beta 3$ - $\beta 4$ sheets in the type IV collagen NC1 domain.

During protomer assembly the NC1 domains of the $\alpha 3$ (IV), $\alpha 4$ (IV) and $\alpha 5$ (IV) chains specifically interact to select chains for triple-helix formation. In Alport syndrome, NC1 domain cysteine substitutions (see Figure 7) are thought to affect the folding of the monomeric NC1 domain, preventing its participation in trimer assembly. The NC1 domain is also important for network assembly, whereby the NC1 trimers of two protomers specifically interact forming a NC1 hexamer. Variants that result in a loss of, or a defect in any of the $\alpha 3(\mathrm{IV}), \alpha 4(\mathrm{IV})$, or $\alpha 5(\mathrm{IV})$ chains result in incorrect folding or assembly of the entire protomer leading to a complete absence of the $\alpha 3 . \alpha 4 . \alpha 5$ (IV) network from the GBM. However in kidney biopsies from affected patients in this family the $\alpha 3$ (IV), $\alpha 4$ (IV) and $\alpha 5$ (IV) collagens were still present in the GBM, implying that the p.Cys1638Tyr alteration must still allow for the correct assembly of the triple helical protomer. It is possible, however, that an organ-specific defect in protomer function rather than assembly could explain the lack of sensorineural hearing loss or ocular defects in this family, although it remains to be determined whether the p.Cys1638Tyr variant could indeed disrupt the dimerization of two protomers at the C-terminus, thus affecting network assembly. 
Further to the New Zealand family, there have been 7 other mutations involving cysteine residues in the NC1 domain (Bekheirnia et al., 2010, Gross et al., 2002, Hertz et al., 2001, Inoue et al., 1999, Knebelman et al., 1996, Wang et al., 2005., Wilson et al., 1997, Zhou et al., 1991) affecting males and females (Figure 7). These mutations are shown together with information of age at the time of diagnosis. From refs 2, 3, 6, 7 and 8 patients were detected during the ages of 6-16 yrs while one was at 31 yrs old. From refs 3 and 2 two males showed ESRF at 14 and $16 \mathrm{yr}$ old, respectively. When clinical information was available, all of the affected individuals appeared to show hearing loss, except for three individuals who had mutations involving C226 (Wang et al, 2005), C177 (Bekheirnia et al., 2010) and C183 (Wilson et al., 2007). The latter report is our own New Zealand family described here. Patients with other mutations of the NC1 domain either lacked a5(IV) in the GBM, or were clinically more severe than the patients with the C177 and C183 mutations, both of which, interestingly involved mutations in the same disulfide linkage.
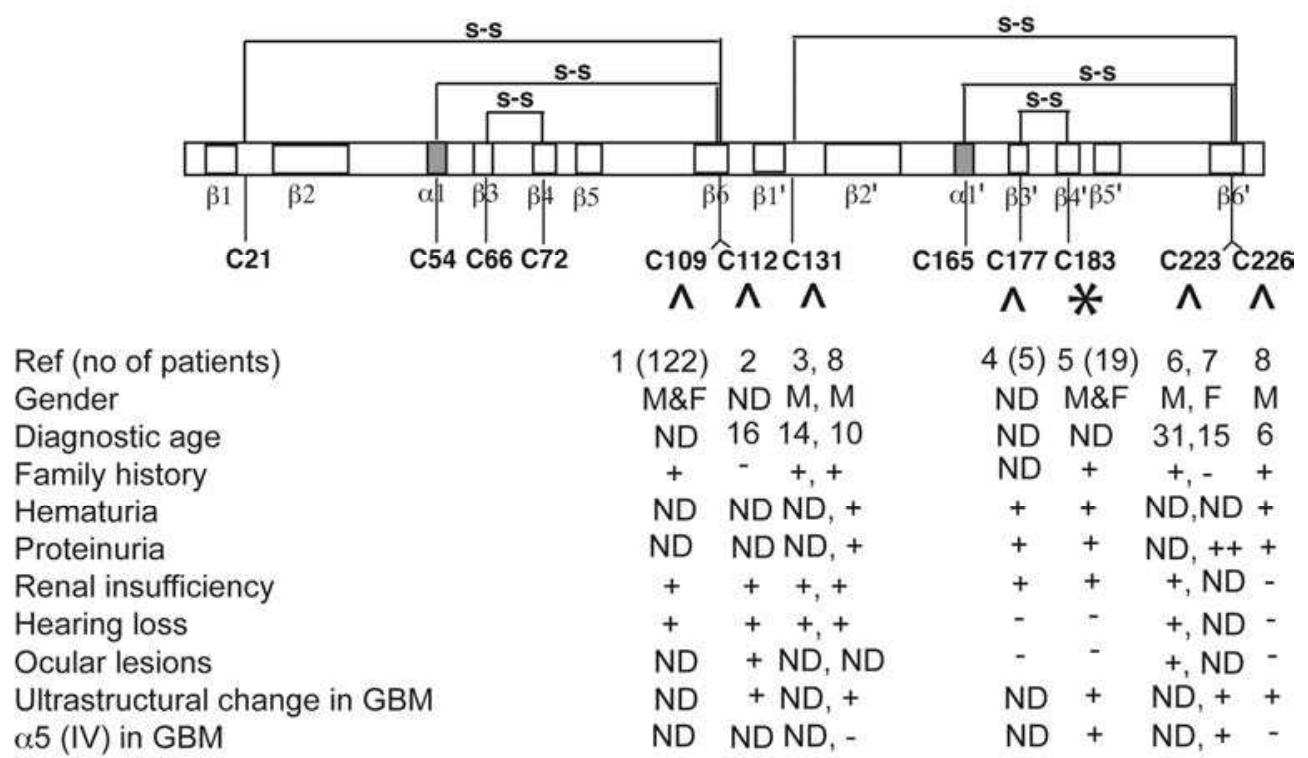

$\begin{array}{ccc}1(122) & 2 & 3,8 \\ \text { M\&F } & \text { ND M, M } \\ \text { ND } & 16 & 14,10 \\ + & - & +,+ \\ \text { ND } & \text { ND ND, }+ \\ \text { ND } & \text { ND ND, + } \\ + & + & +,+ \\ + & + & +,+ \\ \text { ND } & + & \text { ND, ND } \\ \text { ND } & + & \text { ND, }+ \\ \text { ND } & \text { ND ND, }\end{array}$

\begin{tabular}{|c|c|c|}
\hline $4(5)$ & 5 (19) & 6,7 \\
\hline ND & $M \& F$ & $\mathrm{M}, \mathrm{F}$ \\
\hline ND & ND & 31,15 \\
\hline ND & + &,+- \\
\hline+ & + & ND,ND \\
\hline+ & + & $\mathrm{ND},++$ \\
\hline+ & + &,$+ N D$ \\
\hline - & 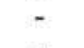 &,$+ N D$ \\
\hline - & - &,$+ N D$ \\
\hline ND & + & $\mathrm{ND},+$ \\
\hline ND & + & $\mathrm{ND},+$ \\
\hline
\end{tabular}

Fig. 7. Depiction of NC1 domain showing locations of cysteine sequence alterations, and the clinical details of patients. Shown are the positions of the beta sheet domains ( $\left.\beta 1-\beta 6, \beta 1^{\prime}-\beta 6^{\prime}\right)$, and alpha helix $\left(\alpha 1, \alpha 1^{\prime}\right)$ and cysteine residues arranged linearly, and their disulfide linkages. Cysteine residue missense mutations of the NC1 domain that have been previously reported are shown $\left({ }^{\wedge}\right)$, together with the cysteine mutation in the New Zealand family (* under cysteine 183; amino acid numbering in this figure is from the start of the NC1 domain, which is one amino acid longer than in our previous report (Wilson et al, 1997). ND, not determined. +, characteristic is present. -, characteristic is absent. M, male, F, female. Refs; 1 (Zhou et al., 1991); 2 (Knebelmann et al., 1996); 3 (Hertz et al., 2001); 4 (Bekheirnia et al., 2010); 5 (Wilson et al., 1997); 6 (Gross et al., 2002), 7 (Inoue et al., 1999); 8 (Wang et al., 2005).

Kobayashi and colleagues constructed a plasmid containing mutations corresponding to a variety of missense or deletion mutations of the NC1 domain of COL4A5, which were grown in a kidney cell line. The results showed that mutations render the collagen chain defective 
in terms of heterotrimer formation between the $\alpha 3, \alpha 4$ and $\alpha 5$ collagen chains, and/or the secretion of the heterotrimer from cells (Kobayashi et al., 2008). After our publication, these researchers further constructed a plasmid containing the mutation corresponding to Cys1638Tyr into the $\alpha 5$ (IV) chain. The results of this experiment showed that heterotrimer formation in the cells and secretion of the $\alpha 5(\mathrm{IV})$ chain in the monomeric form from the cells were markedly decreased compared to cells containing the wild-type chain. However, the heterotrimer that was formed from the mutant chain was still secreted from the cells. They concluded that the residual ability of the mutant chain to form and be secreted may have led to the unique mild phenotype formed in the Alport syndrome family with the Cys1638Tyr mutation (Kobayashi \& Uchiyama 2010).

\section{Renal lesions in carrier women of X-linked Alport Syndrome and Thin Basement Membrane Nephropathy}

Thin basement membrane nephropathy (TBMN) is the most common cause of inherited renal disease and its incidence has been reported to be as high as $1 \%$ of the world population (Kashtan 2005, Tazon et al., 2003, Wang \& Savige 2005). It is defined as diffuse thinning of the GBM characterised by persistent glomerular hematuria, minimal proteinuria, and normal renal function. Genetic studies of TBMN have helped to establish that many patients with benign familial hematuria are actually the carriers of autosomal recessive Alport syndrome, carrying mutations only in the one allele of COL4A3 or COL4A4 (Voskarides et al., 2008). A novel missense mutation of COL4A3 in a Chinese Han consanguineous family was identified and the underlying pathogenic role in the homozygous form was investigated in autosomal recessive Alport syndrome and in the hetrozygous form in TBMN within the identical family (Hou et al., 2007). These studies showed that while TBMN manifest as a dominant disorder in the family with the COL4A3 mutation, Alport syndrome manifested as a recessive disease in the same family. In our experience, by light microscopy the kidney glomerular features of the carrier females (eg V40) of X-linked Alport syndrome in the New Zealand family were relatively unremarkable. However there was occasional periglomerular fibrosis and focal areas of protein casts in occasional tubules associated with epithelial cell atrophy (Fig 8A and 8B).
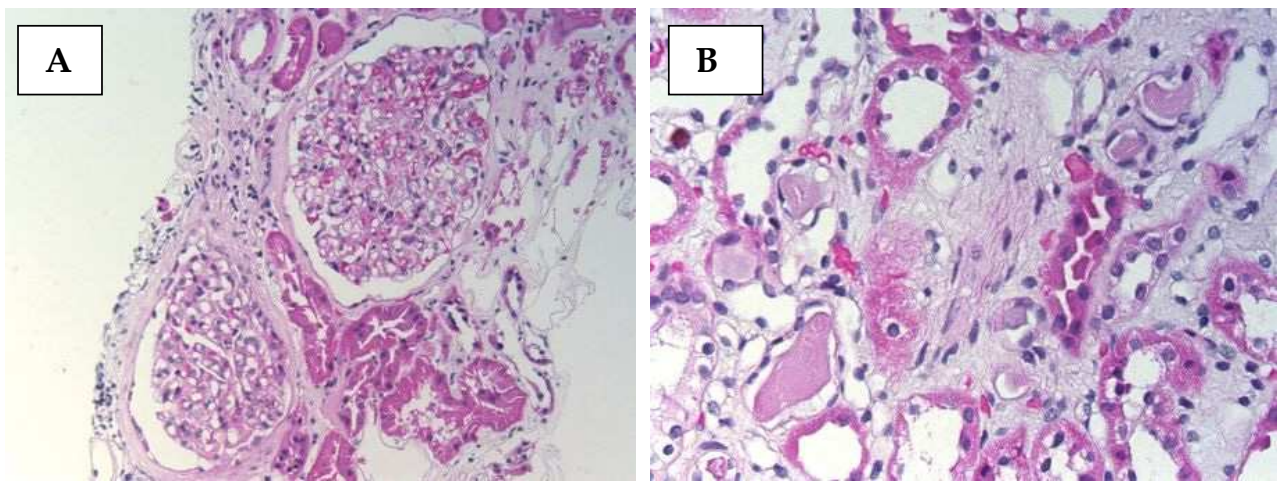

Fig. 8. Histology from a carrier mother (V40) in the New Zealand family with Alport syndrome.

(A) Two glomeruli show periglomerular fibrosis. Glomerular tufts are relatively unremarkable.

(B) Focal areas show protein casts in occasional tubules that show atrophic epithelial cells. 

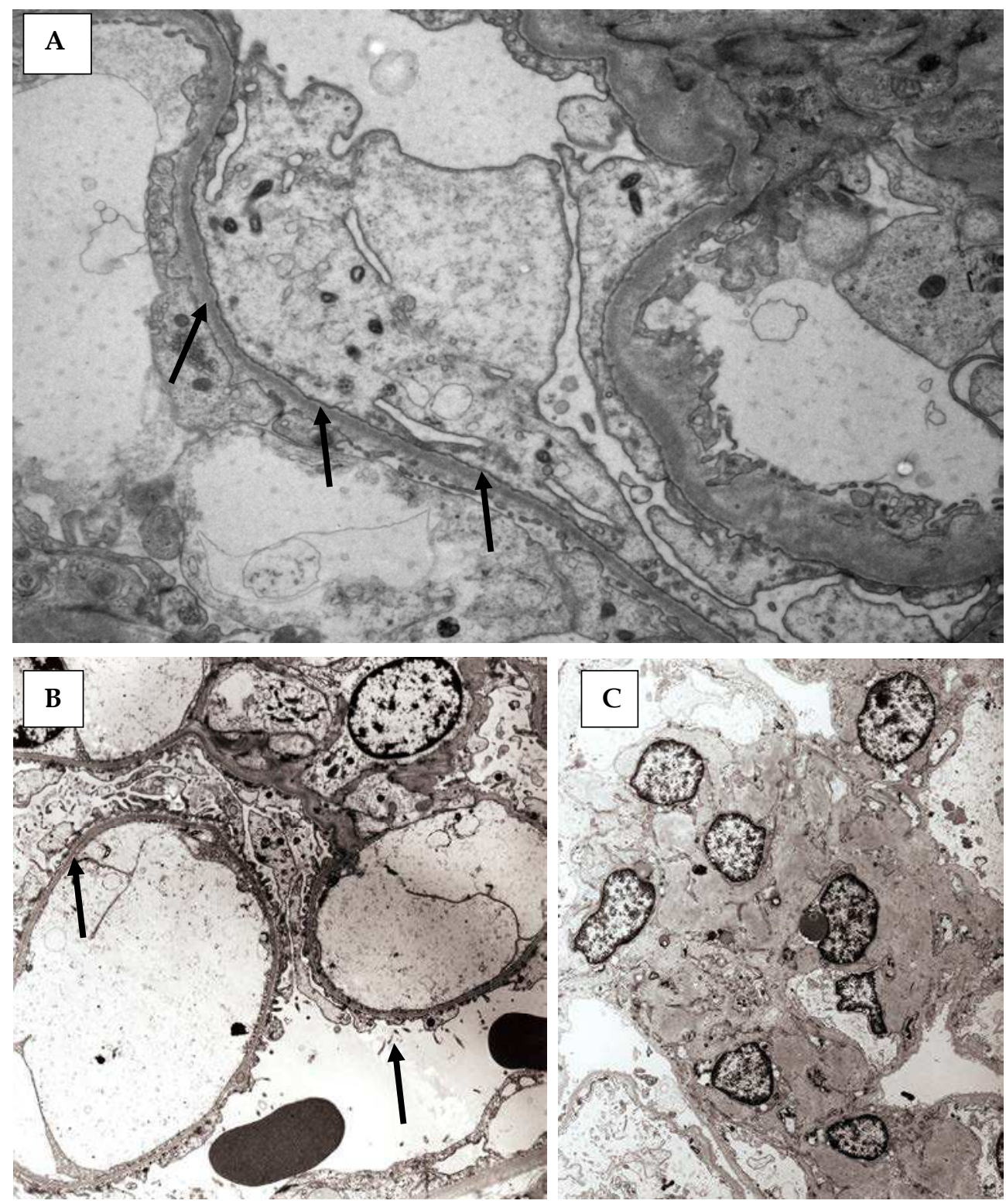

Fig. 9. Electron microscopy of carrier females (V40 and IV28). (A) The same carrier mother (V40) of the Figure 8 and (B) another carrier female (IV28), both showing focal areas of extremely thin GBM (arrows). (C) In addition there are focal areas of irregular GBM thickening. (A x7,400, B x3,000, C x2,100, original magnification respectively).

Electron microscopic findings on one of the carrier women of the New Zealand X-linked Alport syndrome family showed severe thinning of the GBM (Fig 9A) where the thickness 
was approximately $150 \mathrm{~nm}$, and much thinner than the normal GBM (300-400 nm). Another carrier woman also showed focal areas of severely thin GBM (Fig 9B). In addition there were occasional regional areas of thick segments of GBM (Fig 9C). It is notable that the typical basket weave appearance or splitting was not present in the females. One message to take from these studies is that electron microscopic examination of the kidneys in carrier women with clinical symptoms should be mandatory because the light microscopic observations on their own often provide unremarkable findings or only subtle changes and may not show a full range of pathology.

Although TBMN has been regarded as a benign condition with an excellent prognosis, as high as $38 \%$ of COL4A3/COL4A4 heterozygous mutant carriers, of all ages, develop chronic renal failure and $19.5 \%$ progress to ESRF (Voskarides et al., 2008). These authors emphasize a strong association between TBMN and focal segmental glomerulosclerosis (FSGS). Several studies report that TBMN predisposes to premature glomerular obsolescence and that this may then lead to late onset renal insufficiency followed by ESRF (Nieuhof et al., 1997, Nogueira et al., 2000). Other studies suggest that there may be other factors that predispose transition from TBMN to FSGS (Sue et al., 2004). These factors could be due to involvement of modifier genes such as podocyte specific genes or environmental factors.

These findings concur with a previous report (Jais et al., 2003) in that hematuria was observed in $95 \%$ of 323 female carriers of X-linked Alport syndrome. Proteinuria, hearing loss, and ocular defects also developed in $75 \%, 28 \%$, and $15 \%$, respectively. Moreover, the probability of developing ESRF or deafness before the age of $40 \mathrm{yr}$ was $12 \%$ and $10 \%$, respectively, in females versus $90 \%$ and $80 \%$, respectively in men. In their study ultrastructural change of the GBM were found in 26 of 28 carriers and consisted of typically thick and split or alternatively thick and thin GBM in 19 patients. When taken together, our results and those of Jais et al (2003) suggest that TBMN may frequently develop in carrier women with a heterozygous COL4A5 mutation.

\section{Conclusions}

In conclusion, mild forms of Alport syndrome may occur in association with certain mutations in the collagenous domain of the collagen proteins. In addition, we showed a p.Cys1638Tyr mutation occurring within the NC1 domain of COL4A5 in a New Zealand family was associated with a mild form of Alport syndrome. Mild forms of Alport syndrome also occur in females with COL4A5 mutations, in whom there is considerable phenotypic variation. In particular, it appears that electron microscopy carried out in female carriers of COL4A5 mutations reveals much more about the health of their kidneys than does routine light microscopy alone. The abnormalities present in the kidneys of female carriers suggest that with appropriate management of diet and hypertension this could prevent the onset of renal disease in these women. Additional investigations of the pathogenic role of COL4A5 mutations in female members of Alport families, and of the role of the NC1 domain in the New Zealand family, will further help to better understand the role of collagens in the structure and function of the filtration barrier in the GBM.

\section{Acknowledgments}

The authors thank Dr Y Sado, for his generous gift of rat monoclonal antibodies H11, H22, H31, H43, H53 and H63 specific for the $\alpha 1(\mathrm{IV}), \alpha 2(\mathrm{IV}), \alpha 3(\mathrm{IV}), \alpha 4(\mathrm{IV}), \alpha 5(\mathrm{IV})$, and $\alpha 6(\mathrm{IV})$ 
collagen, Dr Rob Walker for clinical advice, and Mr Richard Eisenwood and Ms Gillian Maudsley for carrying out electron microscopy and measurement. This work has been supported by the Otago Medical Research Foundation, the Healthcare Otago Charitable Trust, and the NZ Institute for Cancer Research Trust.

\section{References}

Alport, A. (1927). Hereditary familial congenital haemorrhagic nephritis. Br Med J, Vol.1, pp. 504-506, ISSN 0958-8146

Arup Laboratories: ARUP Online Scientific Resource: ALPORT database display gene, 2011. Available at:

http://www.arup.utah.edu/database/ALPORT/ALPORT_welcome.php?col=loc. Accessed April21, 2011

Barker, D., Denison, J., Atkin, C. \& Gregory, M. (1997). Common ancestry of three Ashkenazi-American families with Alport syndrome and COL4A5 R1677Q. Hum Genet, Vol.99, No.5, pp. 681-684, ISSN 0304-6717

Barker, D., Pruchno, C., Jiang, X., Atkin, C., Stone, E., Denison, J., Fain, P. \& Gregory, M. (1996). A mutation causing Alport Syndrome with tardive hearing loss is common in the Western United States. Am J Hum Genet, Vol.58, No.6, pp. 1157-1165, ISSN 0002-9297

Bekheirnia, M., Berenice, R., Gregory, M, McFann, K, Shamshirsaz, A., Masoumi, A. \& Schrier, R. (2010). Genotype-phenotype correlation in X-Linked Alport syndrome. J Am Soc Nephrol, Vol.21, No.5, pp. 876-883, ISSN 1046-6673

Borza, D., Bondar, O., Ninomiya, Y., Sado, Y., Naito, I., Todd, P. \& Hudson, B. (2001). The NC1 domain of collagen IV encodes a novel network composed of the alpha 1, alpha 2, alpha 5, and alpha 6 chains in smooth muscle basement membranes. J Biol Chem, Vol.276, No.30, pp. 28532-28540, ISSN 0021-9258

Boutaud, A., Borza, D., Bondar, O., Gunwar, S., Netzer, K., Singh, N., Ninomiya, Y., Sado, Y., Noelken, M. \& Hudson, B. (2000). Type IV collagen of the glomerular basement membrane. Evidence that the chain specificity of network assembly is encoded by the noncollagenous NC1 domains. J Biol Chem, Vol.275, No.39, pp. 30716-3024, ISSN 0021-9258

Cosgrove, D., Samuelson, G., Meehan, D., Miller, C., McGee, J., Walsh, E. \& Siegel M. (1998). Ultrastructural, physiological, and molecular defects in the inner ear of a geneknockout mouse model for autosomal Alport syndrome. Hear Res, Vol.121, No.1-2, pp. 84-98, ISSN 0378-5995

Flinter, F., Cameron, J., Chantler, C., Houston, I. \& Bobrow, M. (1988). Genetics of classic Alport's syndrome. Lancet, Vol.29, No.2, pp. 1005-1007, ISSN 1089-4969

Gross, O., Netzer, K-O., Lambrecht, R., Seibolt, S. \& Weber, M. (2002). Meta-analysis of genotype-phenotype correlation in X-linked Alport syndrome: impact on clinical counselling. Nephrol Dial Transplant, Vol.17, No.7, pp. 1218-1227, ISSN 0931-0509

Harvey, S., Zheng, K., Sado, Y., Naito, I., Ninomiya, Y., Jacobs, R., Hudson, B. \& Thorner, P. (1998). Role of distinct type IV collagen networks in glomerular development and function. Kidney Int, Vol.54, No.6, pp. 1857-1866, ISSN 0391-6510

Hertz, J., Juncker, I., Persson, U., Matthijs, G., Schmidtke, J., Petersen, M., Kjeldsen, M. \& Gregersen, N. (2001). Detection of mutations in the COL4A5 gene by SSCP in Xlinked Alport syndrome. Hum Mutat, Vol.18, No.2, pp. 141-148, ISSN 1098-1004 
Hou, P., Chen, Y., Ding, J., Li, G. \& Zhang, H. (2007). Novel mutation of COL4A3 presents a different contribution to Alport syndrome and thin basement membrane nephropathy. Am J Nephrol, Vol.27, No.5, pp. 538-544, ISSN 0360-7615

Huang, T., Cheng, A., Stupak, H., Liu, W., Kim, A., Staecker, H., Lefebvre, P., Malgrange, B., Kopke, R., Moonen, G. \& Van De Water, T. Oxidative stress-induced apoptosis of cochlear sensory cells: otoprotective strategies (2000). Int J Dev Neurosci, Vol.18, No.2-3, pp. 259-270, ISSN 0736-5748

Hudson, B., Reeders, S. \& Tryggvason, K. (1993). Type IV collagen: structure, gene organization, and role in human disease. Molecular basis of Goodpasture and Alport syndromes and diffuse leiomyomatosis. J Biol Chem, Vol.268, No.35, pp. 26033-26036, ISSN 0250-8095

Hudson, B., Tryggvason, K., Sundaramoorthy, M. \& Neilson, E. (2003). Alport's syndrome, Goodpasture's syndrome, and type IV collage. New Engl J Med, Vol.348, No.25, pp. 2543-2556, ISSN 0250-8095

Hudson, B. (2004). The molecular basis of Goodpasture and Alport syndromes: beacons for the discovery of the collagen IV family. J Am Soc Nephrol, Vol. 5, pp. 2514-2527, ISSN 1046-6673

Inoue, Y., Nishio, H., Shirakawa, T., Nakanishi, K., Nakamura, H., Sumino, K., Nishiyama, K., Iijima, K. \& Yoshikawa, N. (1999). Detection of mutations in the COL4A5 gene in over $90 \%$ of male patients with X-linked Alport's syndrome by RT-PCR and direct sequencing. Am J Kidney Dis, Vol.34, No.5, pp. 854-862, ISSN 0272-6386

Jais, J., Knebelmann, B., Giatras, I., De Marchi, M., Rizzoni, G., Renieri, A., Weber, M., Gross, O., Netzer, K-O., Flinter, F., Pirson, Y., Verellen, C., Wieslander, J., Persson, U., Tryggvason, K., Martin, P., Hertz, J., Schröder, C., Sanak, M., Krejcova, S., Carvalho, M., Saus, J., Antignac, C., Smeets, H. \& Gubler, M. (2000). X-linked Alport Syndrome: Natural history in 195 families and genotype- phenotype correlations in males. J Am Soc Nephrol, Vol.11, No.4, pp. 649-657, ISSN 1046-6673

Jais, J., Knebelmann, B., Giatras, I., De Marchi, M., Rizzoni, G., Renieri, A., Weber, M., Gross, O., Netzer, K-O., Flinter, F., Pirson, Y., Verellen, C., Wieslander, J., Persson, U., Tryggvason, K., Martin, P., Hertz, J., Schröder, C., Sanak, M., Krejcova, S., Carvalho, M., Saus, J., Antignac, C., Smeets, H. \& Gubler, M. (2003). X-linked Alport Syndrome: Natural history and genotype-phenotype correlation in girls and women belonging to 195 families: A "European community Alport syndrome concerted action study. J Am Soc Nephrol, Vol.14, No.10, pp. 2603-2610, ISSN 10466673

Jefferson, J., Lemmink, H., Hughes, A., Hill, C, Smeets, H., Doherty, C. \& Maxwell, A. (1997). Autosomal dominant Alport syndrome linked to the type IV collage $\alpha 3$ and $\alpha 4$ genes (COL4A3 and COL4A4). Nephrol Dial Transplant, Vol.12, No.8, pp. 1595-1599, ISSN 0931-0509

Kalluri, R., Shield, C., Todd, P., Hudson, B. \& Neilson, E. (1997). Isoform switching of type IV collagen is developmentally arrested in X-linked Alport syndrome leading to increased susceptibility of renal basement membranes to endoproteolysis. J Clin Invest, Vol.99, No.10, pp. 2470-2478, ISSN 0021-9738

Kalluri, R., Cantley, L., Kerjaschki, D. \& Neilson, E. (2000). Reactive oxygen species expose cryptic epitopes associated with autoimmune goodpasture syndrome. J Biol Chem, Vol.275, No.26, pp. 20027-20032, ISSN 0021-9258 
Kashtan, C. (2005). Familial hematurias: what we know and what we don't. Pediatr Nephrol, Vol.20, pp. 1027-1035, ISSN 0391-6510

Knebelmann, B., Breillat, C., Forestier, L., Knebelmann, B., Breillat, C., Forestier, L., Arrondel, C., Jacassier, D., Giatras, I., Drouot, L., Deschênes, G., ., Broyer, M., Gubler, M. \& Antignac, C. (1996). Spectrum of mutations in the COL4A5 collagen gene in X-linked Alport syndrome. Am J Hum Genet, Vol.59, No.6, pp. 1221-1232, ISSN 0002-9297

Kobayashi, T., Kakihara, T. \& Uchiyama, M. (2008): Mutational analysis of type IV collagen alpha5 chain, with respect to heterotrimer formation. Biochem Biophys Res Commun, Vol.366, No.1, pp. 60-65, ISSN 0006-291X

Kobayashi, T. \& Uchiyama, M. (2010). Mutant-type alpha5(IV) collagen in a mild form of Alport syndrome has residual ability to form a heterotrimer. Pediatr Nephrol, Vol.25, No.6, pp. 1169-1172, ISSN 0391-6510

Miner, J. (2003). A molecular look at the glomerular barrier. Nephron. Exp Nephrol, Vol.94, pp. 119-122, ISSN 1018-7782

Mochizuki, T., Lemmink, H., Mariyama, M., Antignac, C., Gubler, M., Pirson, Y., VerellenDumoulin, C., Chan, B., Schroder, C., Smeets, H. \& Reeders, S. (1994). Identification of mutations in the $\alpha 3(\mathrm{IV})$ and $\alpha 4(\mathrm{IV})$ collagen genes inautosomal recessive Alport syndrome. Nat Genet, Vol.8, pp. 77-82, ISSN 1061-0056

Naito, I., Kawai, S., Nomura, S., Sado, Y. \& Osawa, G. (1996). Relationship between COL4A5 gene mutation and distribution of type IV collagen in male X-linked Alport syndrome. Japanese Alport Network. Kidney Int, Vol.50, No.1, pp. 304-311, ISSN 0391-6510

Naito, I., Ninomiya, Y. \& Nomura S. (2003). Immunohistochemical diagnosis of Alport's syndrome in paraffin-embedded renal sections: antigen retrieval with autoclave heating. Med Electron Microsc, Vol.36, pp. 1-7, ISSN 0914-4287

Nakanishi, K., Yoshikawa, N., Iijima, K., Kitagawa, K., Nakamura, H., Ito, H., Yoshioka, K., Kagawa, M. \& Sado, Y. (1994). Immunohistochemical study of alpha 1-5 chains of type IV collagen in hereditary nephritis. Kidney Int, Vol.46, No.5, pp. 1413-1421, ISSN 0391-6510

Netzer, K., Seibold, S., Gross, O., Lambrecht, R. \& Weber, M. (1996). Use of psoralen-coupled nucleotide primers for screening of COL4A5 mutations in Alport syndrome. Kidney Int, Vol.50, pp. 1363-1367, ISSN 1391-6510

Nieuwhof, C., de Heer, F., de Leeuw, P. \& van Breda Vriesman, P. (1997). Thin GBM nephropathy: premature glomerular obsolescence is associated with hypertention and late onset renal failure. Kidny Int, Vol.51, No.5, pp. 1596-1601, ISSN 0391-6510

Nogueira, M., Cartwright, J.Jr., Horn, K., Doe, N., Shappell, S., Barrios, R., Coroneos, E. \& Truong, L. (2000). Thin basement membrane disease with heavy proteinuria or nephritic syndrome at presentation. Am J Kidney Dis, Vol.35, No.4, E15, ISSN 02726386

Reddan, J., Steiger, C., Dziedzic, D. \& Gordon, S. (1996). Regional differences in the distribution of catalase in the epithelium of the ocular lens. Cell Mol Biol (Noisy-legrand), Vol.42, No.2, pp. 209-219, ISSN 0145-5680

Smeets, H., Melenhorst, J., Lemmink, H., Schröder, C., Nelen, M., Zhou, J., Hostikka, S., Tryggvason, K., Ropers, H., Jansweijer, M., Monnens, L., Brunner, H. \& van Oost, B. (1992). Different mutations in the COL4A5 collagen gene in two patients with 
different features of Alport syndrome. Kidney Int, Vol.42, No.1, pp. 83-88, ISSN 0391-6510

Sue, Y., Huang, J., Hsieh, R. \& Chen, F. (2004). Clinical features of thin basement membrane disease and associated glomerulonephritis. Nephrology, Vol.9, No.1, pp. 14-18, ISSN 1320-5358

Tazon, V., Badenas, C., Ars, E., Lens, X., Mila, M., Darnell, A. \& Torra, R. (2003): Autosomal recessive Alport's syndrome and benign familial hematuria are collagen type IV diseases. Am J Kidney Dis, Vol.42, pp. 952-959, ISSN 0272-6386

Timpl, R., Wiedemann, H., van Delden, V., Furthmayr, H. \& Kühn, K. (1981). A network model for the organization of type IV collagen molecules in basement membranes. Eur J Biochem, Vol.120, No.2, pp. 203-211, ISSN 0014-2956

Voskarides, K., Pierides, A. \& Deltas, C. (2008). COL4A3/COL4A4 mutations link familial hematuria and focal segmental glomerulosclerosis. Glomerular epithelium destruction via basement membrane thinning? Connect Tissue Res, Vol.49, No.3. pp. 283-288, ISSN 0074-767X

Wang, Y. \& Savige, J. (2005). The epidemiology of thin basement membrane nephropathy. Semin Nephrol, Vol.25, pp. 136-139, ISSN 0270-9295

Wang, F., Wang, Y., Ding, J., Yang, J. ((2005). Detection of mutations in the COL4A5 gene by analyzing cDNA of skin fibroblasts. Kidney Int, Vol 67, pp. 1268-1274, ISSN 03916510

Wilson, J., Yoon, H-S., Walker, R. \& Eccles, M. (2007). A novel Cys1638Tyr NC1 domain substitution in a5(IV) collagen causes Alport syndrome with late onset renal failure without hearing loss or eye abnormalities. Nephrol Dial Transplant, Vol.22, No.5, pp. 1338-1346, ISSN 0931-0509

Yoshioka, K., Hino, S., Takemura, T., Maki, S., Wieslander, J., Takekoshi, Y., Makino, H., Kagawa, M., Sado, Y. \& Kashtan, C. (1994). Type IV collagen alpha 5 chain. Normal distribution and abnormalities in X-linked Alport syndrome revealed by monoclonal antibody. Am J Pathol, Vol.144, No.5, pp. 986-96, ISSN 0002-9440

Zhou, J., Barker, D., Hostikka, S., Gregory, M., Atkin, C. \& Tryggvason, K. (1991). Single base mutation in alpha $5(\mathrm{IV})$ collagen chain gene converting a conserved cysteine to serine in Alport syndrome. Genomics, Vol.9, No.1, pp. 10-18, ISSN 1471-2164

Zhou, J. \& Reeders, S. (1996). The $\alpha$ chains of type IV collagen, In: Molecular Pathology and Genetics of Alport Syndrome, Tryggvason K, pp. (80-104), Karger, ISBN 0302-5144, Basel, Switzerland 


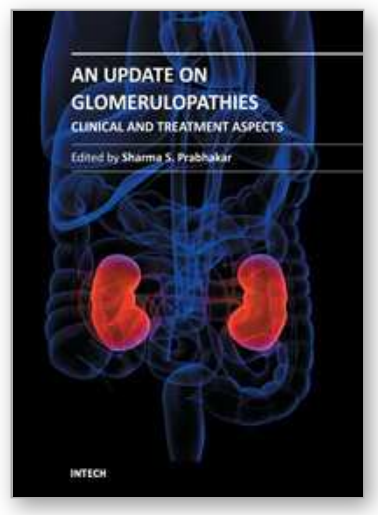

\author{
An Update on Glomerulopathies - Clinical and Treatment Aspects \\ Edited by Prof. Sharma Prabhakar
}

ISBN 978-953-307-673-7

Hard cover, 468 pages

Publisher InTech

Published online 02, November, 2011

Published in print edition November, 2011

An Update on Glomerulopathies - Clinical and Treatment Aspects is a systemic overview of recent advances in clinical aspects and therapeutic options in major syndromes of glomerular pathology. The book contains twenty four chapters divided conveniently into five sections. The first section deals with primary glomerulopathies, and the second section is devoted to glomerulopathies complicating infectious conditions. The third section deals with systemic autoimmune disorders and vasculitides which constitute major causes of glomerular disease and often renal failure. The fourth section includes chapters discussing the glomerular involvement in some major metabolic and systemic conditions. The final section has chapters which relate to some general aspects of glomerular diseases. This book will form an excellent reference tool for practicing and academic nephrology community.

\title{
How to reference
}

In order to correctly reference this scholarly work, feel free to copy and paste the following:

Han-Seung Yoon and Michael R. Eccles (2011). Mild Forms of Alport Syndrome: Hereditary Nephropathy in the Absence of Extra-Renal Features, An Update on Glomerulopathies - Clinical and Treatment Aspects, Prof. Sharma Prabhakar (Ed.), ISBN: 978-953-307-673-7, InTech, Available from:

http://www.intechopen.com/books/an-update-on-glomerulopathies-clinical-and-treatment-aspects/mild-formsof-alport-syndrome-hereditary-nephropathy-in-the-absence-of-extra-renal-features

\section{INTECH}

open science | open minds

\section{InTech Europe}

University Campus STeP Ri

Slavka Krautzeka 83/A

51000 Rijeka, Croatia

Phone: +385 (51) 770447

Fax: +385 (51) 686166

www.intechopen.com

\section{InTech China}

Unit 405, Office Block, Hotel Equatorial Shanghai

No.65, Yan An Road (West), Shanghai, 200040, China

中国上海市延安西路65号上海国际贵都大饭店办公楼 405 单元

Phone: +86-21-62489820

Fax: $+86-21-62489821$ 
(C) 2011 The Author(s). Licensee IntechOpen. This is an open access article distributed under the terms of the Creative Commons Attribution 3.0 License, which permits unrestricted use, distribution, and reproduction in any medium, provided the original work is properly cited. 